\title{
Papiackum Proverbial Discourse and Social Engineering: A reading in Functionalism
}

\author{
Moustapha Reike Fandi*, Fossung Noutock Gilbert, Ph.D \\ Department of African Languages and Linguistics, The University of Yaounde I, Cameroon
}

\author{
DOI: $\underline{10.36348 / \text { sijlli.2021.v04i02.001 }}$ \\ | Received: 26.12.2020 | Accepted: 11.01.2021 | Published: 04.02.2021
}

*Corresponding author: Moustapha Reike Fandi

\section{Abstract}

Nation building is an unending process in most if not all nations of the world. This urge for progress has spurred many nations to work in a bid to changing their status from developing, developed to emerging nations. In this guise, nations are constantly faced with challenges which may be political, economic and socio- cultural in their drive towards national reconstruction. This study therefore examines the pedagogic relevance of Papiackukm proverbial discourse in meeting challenges associated with national development. From the theoretical paradigm of Functionalism, this paper is based on the prism that Papiackum proverbial discourse are speech acts element embedded with norms and values that promote broad-based development by addressing some hurdles related to the process of nation building. The Papiackum is a speech community in the Ngoketunjia Division, North West Region of the Republic of Cameroon.

Keywords: Proverb, Social Engineering, Discourse, Functionalism.

Copyright (C) 2021 The Author(s): This is an open-access article distributed under the terms of the Creative Commons Attribution 4.0 International License (CC BY-NC 4.0) which permits unrestricted use, distribution, and reproduction in any medium for non-commercial use provided the original author and source are credited.

\section{INTRODUCTION}

Every society is composed of human beings who interact and socialize with one another. In the course of socialization, they project certain norms and values that bind its members in their urge towards societal progress. In this light, many African communities employ orature especially proverbial discourse to embellish interaction and as a catalyst for societal growth. This view is enshrined in Mode [1] who notes that, proverbial expressions are useful in the socio-cultural and educational development of the Yoruba people of South West Nigeria prior to the introduction of western education into the land. This situation is not circumscribed only to the Yoruba community but can also be a reflection of the Papiackum community with folk discourse that foster broad based development of the said society and the Cameroonian nation at large in its drive towards emergence by 2035 .

The aim of this paper therefore is to attempt a Functionalist analysis of Papiackum proverbial expressions in order to demonstrate how this folk discourse helps in promoting national reconstruction. In other words, it examines the norms and values projected by these proverbs and their role in addressing challenges associated with national development. From this perspective, it is based on the hypothetical consideration that, Papiackum proverbs are a veritable source in the resolution of political, economic and socio-cultural hurdles in the drive towards nation building.

\section{Geopolitical Presentation, Social History and Occupation}

Baba I whose culture is the object of this study, is among the thirteen village that constitute present day Ngoketunjia Division in the North West region of the Republic of Cameroon. This village is situated at about forty Kilometers form Bamenda along the ring road that leaves Bamenda to Nso. In the North, it shares a boundary with Oku which is a Sub Division in Bui Division. In the East, there is Babessi village. In the South East, it shares a short boundary with Bangolan which is among the four Fondoms that constitute Babessi sub Division. In the South, there are Bambalang and Bamunka Fondoms which are within Ndop central sub Division. In the West, there is Babungo Fondom which constitutes one of the four Fondoms of Babessi Sub Division. As regards their origin, the Papiackum came from Refum which was capital of the defunct Tikari Kingdom now known as Mbamkin in the Adamawa region of Cameroon. They came from some places in North Cameroon notable Maroua, Garoua and Ngaoundere. They left North Cameroon during the Jihad wars and moved to the South. The Papiackum call their Fondom "paick" which 
means "to leave". This coinage is the result of their history marked by migration before settling to their present site. Structurally, they have institutions that perform political and socio-cultural duties. Politically, mwarngang is the highest institution that has the power to sanction cases of indiscipline, enthrone a new leader and judge issues related to murder. Also, there is the shag known as the women's parliament whose role is visible in times of conflict or war as a solidarity group. In terms of occupation, these people practise agriculture with rice farming as their principal activity.

\section{Definition of Concepts}

The key concepts that need proper scrutiny are proverb, discourse and social Engineering. To begin with Mieder [2] defines proverb as a short, generally known sentence of the folk which contains wisdom, truth, morals and traditional views in a metaphorical, fixed and memorable form which is handed down from generation to generation. This projects the view that, proverbs are an indispensable component of folklore embedded with wise knowledge in diverse areas of social life that is transmitted orally to posterity. In a similar manner, Russo [3] refers to proverb as a short but complete statement carrying folk wisdom in a general and often figurative form to guide behavior in a recurrent situation. This definition of proverb points to its role in shaping attitude and moralizing society.

Secondly, the concept of discourse is worth elaborating. In this connection, Foucault [4] asserts that, discourse is socially constructed knowledge of some aspects of reality. To expatiate on this view, Leeuwen [5] affirms that, socially constructed knowledge is one which has been developed in specific social contexts in ways that are appropriate to the interests of social actors in these contexts. Papiackum proverbs are considered as folk discourse because they are extended stretch of connected speech which can only be interpreted in their entirety based on their contexts of usage.

In addition, there is the concept of Social Engineering where Adjiboloso [6] refer to it as the human practice of creating, applying, modifying ideas, knowledge, principles, models, theories, techniques, tools and associated action plans to social, economic, political and educational problems through what he terms "human factor development" In other words, he points out that, it englobes the amalgamation and management of a series of human actions aimed at achieving objectives through the problem solving process in a bid to improve the living conditions, the quality of life and well-being of every community member. He further notes that, the human factor represents the qualities or character and relationships of people in a community and its impact on one another and the society in question. This entails that human interaction embedded with positive human factors can impact the society positively in its quest for a progress.

\section{LITERATURE REVIEW}

There exist a number of scientific publications on discourses surrounding proverbial usages as scholars have analyzed them from different perspectives and cultural settings. To begin with, Dei [7] examines African indigenous proverbs and the pedagogic relevance for youth education using Kiembu of Kenya and Igbo of Nigeria as case studies. From the prism of a com- parative approach to the study of African proverbs, this study holds that, within the African traditional context, proverbs as a way of knowing are deeply embedded in the community's cultures, histories, indigenous cosmologies and world views. To render the main thrust of this study, he presents some Kiembu proverbs thus; "in-laws live together and die as friends" which hinges on the importance of teaching about family, community and responsibility. Secondly, he mentions the proverb thus, "short cuts are not always the safest" to educate youths on the essence of hard work and self-determination. As for lgbo proverbs, he cites the proverb thus "it is a pot of water that is already half full that the world would like help in filling to the brim "to note that, if one is too lazy to do any work then the brim "to note that if one is too lazy to do any work then others will also be too lazy to help. This study like the present one focus on the didactics of proverbs but the present one further to show how it is relevant in bread based development.

Hussein [8] analyses the role of African proverbs in creating and perpetuating gendered culture. From the prism of post-modern theory of power relationship between social groups and the role of language to mediate the said relationship, it explores the implication of gender stereotypes. From this perspective, he notes that, there are proverbs that reveal society's denial of women's possession of separate psychological, material and social existence outside men. To point out that a wife's identity of personality is subsumed into that of her husband as reflected in the Oromo proverb thus "The face of water is the earth; likewise the face of wife is the husband". Secondly, he presents proverbs that portray women as sexual objects as reflected in the lgbo proverbs thus "a woman carrying a vagina would ask to be sexed, that the vagina is her own, but when it causes trouble, the real owner (of the vagina) would be looked for". In addition, he cites proverbs that convey the social, biological and psychological inferiority of women as echoed in the Oromo proverb thus, "The management of a woman leaves the corral door closed for the whole day ". This study dwells on the role of proverbs in depicting gender stereotypes but the present study goes further to advocate gender equality as bedrock of social progress.

Abou-Zaid [9] traces the link between folklore, proverbs and economic behavior in the United States of American. This study is based on the idea that, the observed economic behavior in America is to an extent influenced by the proverbs and sayings. In terms of 
consumption, he notes that, consumerism controls the society in keeping with a famous proverb thus, "keeping up with the Jones" which captures the social pressure of the society on individuals to over consume products that they are not in need of. As for work orientation, he posits that, there are popular proverbs and idioms used to express the value of hard work and to praise hard workers as echoed in the proverb thus "Action speaks louder than words", " Early birds catch the worms", "money doesn't grow on trees", and "wishes won't wash dishes". As concerns entrepreneurs, he posits that, they place high value on risk taking and profit as reflected thus," Nothing ventured, nothing gained" and "No pain, no gain". This study and the one under study provide folk knowledge that can spur economic progress but the present one also examines values that can assists other solving in political and socio-cultural problems.

\section{THEORETICAL FRAMEWORK}

The theoretical praxis adopted for this study is Functionalism which emerged in the early twentieth century with Bronislaw Malinowski and A.R. Radcliffe Brown having the greatest influence on its development from their post in Great Britain and elsewhere. Two versions of Functionalism developed between 1910 and 1930 known as Malinowski's bio cultural or psychological Functionalism and structural Functionalism, the approach advanced by Radcliffe Brown. Functionalists seek to describe the different parts of a society and their relationship by means of an organic analogy which compares the different parts of a society to the organs of a living organism where the organism is able to live, reproduce and function through the organized system of its several parts and organs. Like a biological organism, a society is able to maintain its essential processes such as religion, kinship and the economy where the organs and individuals were the cells in this social organism. Functionalist analyses therefor examine the social significance of phenomena that is, the function they serve a particular society in maintaining the whole. In other words, this theory is based on the assumption that socio-cultural institutions and practices should be understood in terms of the functions they carry out in sustaining the larger social and cultural system.

\section{Papiackum Proverbial Discourse and Political Challenges}

Papiackum folk discourses are embedded with norms and values that can resolve some political challenges associated with good governance in the process of nation building. Good governance has to do with the transparent management of public affairs for the benefit of the entire community or nation. To begin with, the quest for the efficient and equitable distribution of resources is articulated in the proverb thus: mvié mà nkwé ndiáx ndáp ndzi - ndzém Fetch i wood sleep house darkness.
This proverb is literally stated as "I have fetched firewood yet slept in a house without light". To "fetch" represents the act of working to attain an objective, "wood" symbolize the proceeds of hard work while sleeping in a house with darkness stands for the fact that one is unable to enjoy the proceeds of his or her labour and by implication the resources of the community. This is therefore a satire against a society whereby the resources are not equitably distributed for the benefit of all and as a result leads to rising poverty levels. It also notes that the fight against self-interest should be intensified so the resources of the nation are used for its development and not for selfish reason. From this perspective, this proverb insinuates that for members of a community to develop a sense of belonging, there is the urgent need to efficiently manage and distribute resources for the well-being of the entire population.

Secondly, Papiackum folk epistemology projects the view that the promotion of accountability is indispensable for political governance as reflected in the proverb thus: $\int$ iáx mwé mì nt $\int a ́$ mbó máb Time child never than for mother his.

This proverb is literally stated as "A child is never old in front of his mother" This means that even when a child becomes a grown up, he or she is still considered as a child in front of parents. It therefore underscores the view that a child will always render accounts of his activities to his parents no matter the age. In other words, parents continue to serve as guides to the moral and cognitive development of their offspring. By extension, the external link between children and parents is likened to that of a community and its members or the nation and its citizens. From a similar perspective, the child symbolizes the citizen of a nation while mother represents a nation or a country. This symbolism underscores the view that citizens should know that they are eternally accountable to their countries of origin. This is effective in the sense that leadership should create a favorable atmosphere where community members irrespective of their ages, social class and sex should always render accounts of their actions as well as the smooth functioning of political institutions in their respective domains to facilitate common well-being.

Still in the light of fostering accountability as a political philosophy, it is echoed in the proverbial expression thus: wú nál mbáb ndáp Death sleeps opposite house.

This proverb is literally stated as "Death sleeps just opposite your house" Death is personified as sleeping to stress that it is beside the bed waiting to take away a defaulter or culprit. The expression "opposite the house" points to the fact that, death is nearer to those who look for it. This proverb therefore expresses the idea that, he who indulges in evil should know that 
he will render accounts to death. In the Papiackum society, this proverb is uttered in a context where people do not respect tradition and which must lead to death. In this case, tradition can metaphorically symbolize the laws of a community and death represents the punishment that awaits defaulters. This means that leadership should ensure that those who do not respect the laws of the community which aims at ensuring social progress should be punished accordingly.

In addition as regards the commitments in ensuring the respect of the rule of law, it is enshrined in the proverbial expression thus: á tó wù ngán pá mwé, ló kù pí yáp If come you country people take foot dance their.

This proverb is literally stated as "if you visit someone's country, follow their footsteps". The word "footsteps" represents the customs or the laws of a people. It therefore highlights the idea that people should learn to respect the laws of a community or nation wherever they find themselves. It also puts forth the view that, every society has its specificities in terms of its norms that any newcomer must adhere to in order to live in harmony with the member of the said society. From another perspective, this proverb insinuates that every nation has laws and must ensure its strict respect by all citizens or non-citizens for its development.

Furthermore, in the light of promoting social justices as a political ideology, there is the proverb thus: pò mí tréu páx á yòm láx One cannot plant pumpkings it bear calabashes.

This proverb is literally stated as "one cannot plant pumpkins and find them bear calabashes" It expresses the view that one only harvests what was planted. This means that every good result is the consequence of a good job and vice versa. In other words, it notes that people should exercise honesty and only expect what rightly belongs to him or her. From another dimension, this proverb calls on leadership to promote a just society or a society where meritocracy is held in high esteem. In this regards, it calls on political leadership to intensify the promotion of transparency and accountability so that success is the result of hard work for the wellbeing of the entire community.

Moreover, the promotion of transparency is projected in Papiackum folk discourse as cornerstone of governance. This view is echoed in the proverb thus: máfì mó fàndí Road moh fendi.

This proverb is literally stated as "The road of Moh Fendi". The name "Moh Fendi" is well known during the migratory history of the Papiackum. We are made to understand that when the Papiackum left Menyog before it was day time, a notable by name Moh Fendi went and stood on the right path and directed the people into a swampy area where many of them sank completely. From this historical information, among the Papiackum, when someone says that he was shown Moh Fendi's path, it means that he was deliberately misdirected. The name "Moh Fendi" therefore is a historical symbol that satirises deceit. Through this satire, this proverb insinuates that, for there to be durable social progress there is the need to promote the culture of honesty and transparency. Also, a society built on truth inspires its members to develop interest its affairs thus reinforcing togetherness in the pursue of common goals.

\section{Papiackum Proverbial Discourse and Economic Challenges}

Every nation in its quest for nation building meets economic challenges related to the promotion of economic growth, development and sustainable development. In this light, Papiackum folk psychology via proverbial expressions implicitly presents norms and values that create a favorable atmosphere for economic prosperity. To begin with, it brings to the fore norms and values that lead to human capital development to champion the process of development. This is the case with the proverbial expression thus:

This proverb is literally stated as "A person with no value shouts a lot" The idea expressed in this proverb is also expressed in the popular saying that "an empty vessel makes the loudest noise" The word "nothing" means baseless while "shouts" gives the impression that if what is said has some sense in it then the speaker has no reason to shout in order to be heard. This proverb therefore criticizes people who talk too much with little or no action. From this few, it notes that participation in economic development does not rely on too much talking but rather on action. This also highlights the idea that much time should be spent on concrete action than on baseless actions. This idea is encapsulated in the view expressed in the expression that time is money. This insinuates that only action oriented human resources is adapted to push a nation towards economic prosperity or emergence.

Still in the light of human capital development, there is the proverbial expression thus; mwé ndóm ndóm nt û ndzál ngá Someone nothing nothing is shouts a lot.

This proverb is literally expressed as "The buyer is a thief". It is usually evoked in a context of judicial proceedings where something was stolen and sold to another person. The word "thief" presents the idea of satisfying an individual interest. It also points to the fact that the buyer and the thief are punishable by law. Conversely, it implicitly makes the claim that if there is no buyer theft will be greatly reduced in society given that there will be no market for stolen articles. From this perspective, this proverb insinuates that, for there to be economic development, there is the need to 
shun corruption so that resources be it material or financial is not mismanaged or used for individual interests. This new is corroborated by Mtapuri [10] who asserts that it is a curse which needs to be addressed given its profound costs to society which are socioeconomic, political and psychological in nature.

In addition, in the light of the supply of labor and economic progress, there is the proverb thus: púe pà fóx Children are riches.

This proverb is literally stated as "children are riches" It highlights the view that children are a source of wealth. This means that even if a man did not have much property but has many children, he was considered as a rich man. The projection of children as riches in this proverb express the idea that, they are considered as riches if they are ready to work for the progress of the community. Conversely, it also implicitly holds that children who are not hardworking will serve as liability to a nation given that their participation to national development will be insufficient to lead to sustainable development. In cognizance with the fact that Papiackum is a rural community, children can partake in agriculture to reduce hunger, increase in the Gross Domestic Products to ease the path towards economic emergence.

Furthermore, Papiackum folk epistemology traces the link between virtues and economic progress as reflected in the proverbial expression thus: lin mbá \kórí tfàmò mbám Name good than money.

This proverb is literally stated as "A good name is more than money" This expresses the idea that the greatness of a person in the community does not depend on the amount of money he or she has but on his good deeds that can lead to community progress. On the other hand, it is a satire against those who think that one needs to have much money in order to participate in the construction of the community. To expatiate on this view, Han, Liauw and Juntz [11] posit that, there is a relationship between moral identity and development. To make this idea clearer, he quotes Blasi et al., [12] who affirm that the development of moral identity is similar to the development of meaning of life. This means that for one to participate in the economic progress of the community, he or she should be guided by moral attributes and a sense of responsibility

Moreover, to project the role of virtues in economic progress, there is the proverbial expression thus: mbám ndzámkə̀rì wù t fóx nkpé Money too much you become slave.

This proverb is literally presented as "Too much money, one becomes a slave" This puts forth the idea that just like money is necessary for the reconstruction of a society, it can also distablilise it. The word "slave" paints the picture of a person who has too much money but cannot put it into concrete use or for the benefit of the community. From another perspective, it stresses the fact that, those who have too much money have the tendency to look for more and forget about their responsibility as active participants in the path towards economic prosperity of their communities. The central message here is that money should not lead to evil or isolation but should be invested into projects that can lead to the economic progress of the community and the nation at large.

\section{Papiackum Proverb Discourse and Socio-Cultural Challenges}

Papiackum folk discourse brings to the lamplight norms and values that address some sociocultural challenges. The first of these challenges is the promotion of peaceful co-existence given that developmental objectives cannot be attained in an atmosphere void of peace. This view is reflected in the proverb thus: nt ù̀ píp wó? Sit wait who

This proverb is literally stated as "I am sitting to wait for who? It is in the form of an interrogative statement whereby a person disguises his lazy altitude with the pretext of waiting for another person to do his work. The verb "sit" presents an image of inactivity while expecting future success. The central message is that when one does not work hard and keeps on expecting favors from other people, there is bound to be conflict when the said expectation is not met. This means people should be self-reliant to reduce dependency, the possibility of indulging in conflicts thus promoting social harmony and community progress.

Still in the light of peaceful co-existence, Papiackum folk discourse believes that, it is possible if gossiping is reduced to the barest minimum as reflected in the proverb thus: ngál sólà Country gossip

This proverb is literally stated "Country of gossiping" The word "country" projects the image of a group who share certain attributes and "gossiping" paints a picture of idleness and evil machinations towards one another. It therefore underscores the view that since some people have embarked on idleness, gossiping becomes their hobby. The word "gossiping" has a negative connotation given that it is linked to hatred where people accuse others baselessly thus causing discord in the community. The mention of a country made of only gossipers is hyperbolic and humorous to show the extent to which gossiping can be very destructive to families, communities and a nation. This proverb therefor criticizes laziness or idleness and recommends hard work which leads to individual as well general well-being. Conversely, this proverb also implicitly makes the claim that leadership should put in place policies that will occupy the population thus reducing the possibility of gossiping and discord in families and communities. 
In addition, jealousy which is part and parcel of communal life is highly satirized by Papiackum folklore as a challenge to societal progress. This view is articulated in the proverb thus:

yé wó mbel-í?

See who fine him.

This proverb is literally stated as "He who sees and likes it". We learned from our informant that this proverbial name is given to family members who have been victims of hatred and calumny due to their riches or investments. From this information therefore, it is a proverbial name that criticizes those who do not appreciate the effort of other people but always find fault in it. In other words, it addresses jealousy that reduces human capacity to be appreciative. The message here is that people should learn to appreciate each other for their individual effort and can serve as a motivating factor to spur people to work hard in order to ameliorate their being condition and that of their communities. It also underscores the idea that the leadership in any community or nation should ensure that poverty is brought to its barest minimum so as to reduce envy and the possibility of having conflicts that distort the smooth functioning of society.

Furthermore, Papiackum wit frowns at the excessive quest for materialism as depicted in the proverb thus:

à pál mwé ntfá mbám

It fine person more money.

This proverb is literally stated as "A person is better than money". We learn from our informant that this proverbial name is given to someone who is a victim of ritual killings. The idea here is that ritual killing is often associated with the quest for riches. From this perspective, it criticizes riches that is not hard earned and which puts human life into jeopardy. In other words, it satirizes material possessions at the expense of human relationship. Conversely, it projects the idea that material things do not give pleasure and happiness as a cordial relationship with fellow human beings. It therefore calls for patience and hard work in the quest for a better living condition.

Also, Papiackum wisdom evokes civic participation as a value that is worth promoting as portrayed in the proverb thus:

pà ndż̀ tfî nkállò

They don't force love.

This proverb is literally stated as "love is not forced" this expresses the view that no matter what is said or done, love develops naturally. This means that for people to participate in the progress of their communities, they must develop natural and unconditional love for their country. It is because of this that people can participate in rebuilding it without asking what their country has done for them. The central message here is that love is the motivating factor in any true civic engagement.

\section{CONCLUSION}

This paper presents the link between Papiackum folk pedagogy and social engineering programs. In this light this paper has demonstrated that Papiackum indigenous knowledge through proverb and riddles are relevant in addressing political, economic, social and cultural challenges. The concept of social engineering is based on the postulation that the quest for a principled civil society via a positive human factor should be the watch word for a civil society in the quest for human development.

\section{REFERENCES}

1. Mode, A. M. (2015). Proverbs as panacea to peaceful co-existence in Northern Nigeria. Journal of Humanities and social science. 20(9), 55-60.

2. Mieder, W. (2004). Proverbs. A Handbook. London, Green wood press.

3. Russo, J. E., \& Dosher, B. A. (1983). Strategies for multiattribute binary choice. Journal of Experimental Psychology: Learning, Memory, and Cognition, 9(4), 676.

4. Foucault. (1977). The Archaeology of knowledge, London, Tavistock.

5. Leauwen, T.V. (2015). Introducing social semiotics. London Rutledge.

6. Adjiboloso, S. (2006). Developing civil society: Social order and the human factor. Burlington: Ashgate publishing company.

7. Dei, S. J. (2013). African indigenous proverbs and the institutional and pedagogic relevance for youth education: A Ghanian case study. Canadian and international Education, 40(1) 21-40.

8. Hussein, W. J. (2005). The social and ethnocultural construction of masculinity and femenity in African proverbs. African Study Monographs, 26(2), 59-87.

9. Abduo-Zaid, S. A. (2013). The U.S folklore proverbs and economic behavior. Economics and Sociology. 6(2), 126-134.

10. Mtapuri, O., \& Giampiccoli, A. (2016). Towards a comprehensive model of community-based tourism development. South African Geographical Journal, 98(1), 154-168.

11. Han, H., Liauw, I., \& Kuntz, A. F. (2019). Moral identity predicts the development of presence of meaning during emerging adulthood. Emerging Adulthood, 7(3), 230-237.

12. Blasi, P. (2013). The origin of galactic cosmic rays. The Astronomy and Astrophysics Review, 21(1), 70. 